\title{
Putusan Hakim Pidana Yang Berkeadilan Substantif Melalui Pendekatan Hukum Progresif Dalam Perspektif Penologi
}

\author{
Ferdy Rizky Adilya \\ Alumni Program Studi Magister Ilmu Hukum \\ Program Pascasarjana Universitas Islam Bandung \\ e-mail: feradilya@gmail.com
}

\begin{abstract}
Abstrak- Sejatinya pelaksanaan tugas dan kewenangan seorang hakim dilakukan dalam kerangka menegakkan kebenaran dan keadilan dengan berpedoman pada hukum, undangundang, dan nilai-nilai keadilan yang hidup dalam masyarakat. Putusan hakim pidana yang bersifat progresif dapat menjadi sarana perwujudan dari keadilan substantif. Penelitian ini mengkaji bagaimana putusan hakim pidana yang bersifat progresif dapat mencapai kebenaran dan keadilan yang membawa kesejahteraan masyarakat. Hasil penelitian menyimpulkan bahwa putusan hakim yang bersifat progresif memiliki konsep bahwa hukum adalah untuk manusia, sehingga antara hukum, kemanusiaan, dan moralitas saling berkaitan satu sama lain. Putusan tersebut juga bersifat legalistic, visioner, dan berani melakukan terobosan (rule breaking) dengan tujuan mencapai kebenaran dan keadilan.
\end{abstract}

\section{Kata Kunci: Putusan Hakim Pidana, Kebenaran dan Keadilan, Hukum Progresif.}

Abstract-Actually, the implementation of duties and authorities of a judge is carried out in the framework of upholding truth and justice in accordance with the law, regulations, and values of justice that live in society. Progressive criminal judge decisions could manifest substantive justice. This study examines how progressive criminal judge decisions could uphold truth and justice that brings social welfare. This study concluded that progressive criminal judge decisions has the concept that law is for humans as law, humanity, and morality has a relationship with each other. Such decisions were legalistic, visionary, and dared to make rule breaking to uphold truth and justice.

Keywords: Criminal Judge Decisions, Truth and Justice, Progressive Law.

\section{A. PENDAHULUAN}

Dalam diri hakim diemban suatu amanah agar peraturan perundang-undangan diterapkan secara benar dan adil, dan apabila penerapan peraturan perundangundangan akan menimbulkan ketidakadilan, maka hakim wajib berpihak pada keadilan (moral justice) dan mengenyampingkan hukum atau peraturan perundangundangan (legal justice). Hukum yang baik adalah hukum yang sesuai dengan hukum yang hidup dalam masyarakat (the living law) yang tentunya sesuai pula atau merupakan pencerminan dari nilainilai yang berlaku dalam masyarakat (social justice) (Bagir Manan, 2000:263). Keadilan yang 
dimaksud di sini, bukanlah keadilan yang bersifat formil, tetapi keadilan yang bersifat materil/substantif yang sesuai dengan hati nurani hakim.

Allah SWT berfirman dalam Qur'an nya Surat An-Nisa ayat 58 yang berbunyi:

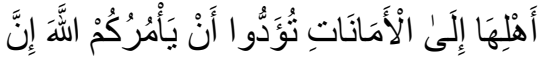

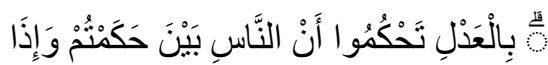

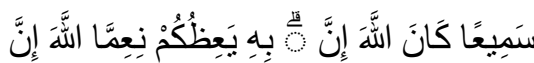$$
\text { بَصِيرًا }
$$

Artinya: "Sungguh, Allah menyuruhmu menyampaikan amanat kepada yang berhak menerimanya, dan apabila kamu menetapkan hukum di antara manusia hendaknya kamu menetapkannya dengan adil. Sungguh, Allah sebaik-baik yang memberi pengajaran kepadamu. Sungguh, Allah adalah Maha Mendengar, Maha Melihat." (AlQur'an Al Karim dan Terjemahnya, 2002:69).

Hakim mempunyai kedudukan yang penting dalam suatu sistem hukum, begitu pula dalam sistem hukum di Indonesia, karena hakim melakukan fungsi yang pada hakikatnya melengkapi ketentuan-ketentuan hukum tertulis melalui penemuan hukum (rechtvinding) yang mengarah kepada penciptaan hukum baru (creation of new law). Fungsi menemukan hukum tersebut harus diartikan mengisi kekosongan hukum (recht vacuum) dan mencegah tidak ditanganinya suatu perkara dengan alasan hukumnya (tertulis) tidak jelas atau tidak ada. (Mochtar Kusumaatmaja, 2002:99).

Pada pokoknya, penemuan hukum yang dilakukan oleh hakim, berawal dari peristiwa hukum konkret yang dihadapkan kepada hakim untuk diputuskan, sehingga sudah seharusnya putusan hakim memenuhi dimensi keadilan, kepastian hukum dan juga kemanfaatan. Sebenarnya sangat sulit sekali mewujudkan ketiganya dalam suatu putusan, sehingga kadangkala putusan hakim dikatakan sebagai putusan yang tidak adil, nyeleneh, ataupun putusan yang mengoyak dan tidak mendengarkan rasa keadilan masyarakat, dan sebutan yang lainnya, putusan yang demikian 
Ferdy Rizky Adilya, Putusan Hakim Pidana Yang Berkeadilan Substantif Melalui Pendekatan...

itulah yang menimbulkan
kontroversi serta polemik
dikalangan masyarakat luas
maupun kalangan ahli ataupun
pemerhati hukum.

Keadaan yang sedemikian itu, seharusnya dapat menggugah dan memanggil hati nurani para hakim untuk menemukan hukum melalui putusan-putusannya yang bersifat progresif demi membantu bangsa dan negara keluar dari keterpurukan, dan juga mengerti akan keinginan dan kebutuhan rakyat serta mengabdi pada keadilan, kesejahteraan dan kepedulian terhadap seluruh warga bangsa pada umumnya, (Satjipto Rahardjo, 2004:1) dan untuk itulah diperlukan langkah-langkah hukum yang bersifat progresif melalui penemuan hukum yang dilakukan oleh hakim, yang sesuai dengan metode-metode penemuan hukum yang selama ini ada dalam praktik, sehingga diharapkan akan dihasilkan putusan-putusan hakim yang bersifat progresif yang bermanfaat bagi perbaikan wajah penegakan hukum dan peningkatan kehidupan berbangsa dan bernegara bagi seluruh rakyat Indonesia.

Penemuan hukum yang dilakukan oleh hakim pidana melalui penalaran hukum yang bersifat progresif, salah satunya dapat ditinjau dengan penalaran hukum perspektif penologi yang bersifat progresif. Perspektif penologi disini, berarti memandang dan menggunakan ilmu pengetahuan penologi. Ruang lingkup penologi dalam hal ini meliputi jenis pidana, tujuan pemidanaan, efektifitas pemidanaan, dan dampak pemidanaan. Putusan hakim yang bersifat progresif dalam perspektif penologi fokus meliputi kepada penalaran hukum dalam konsekuensinya terhadap jenis pidana yang akan dijatuhkan, tujuan pemidanaan yang efektif secara special deterrent dan special prevention terhadap pelaku tindak pidana dan general detterent dan general prevention terhadap masyarakat juga dampak pemidanaan kepada pelaku dan atau kepada korban (masyarakat). 
Dengan demikian, putusan hakim pidana yang bersifat progresif sebagaimana juga merupakan sarana perwujudan dari keadilan substantif melalui penalaran hukum perspektif penologi diharapkan dapat mampu memecahkan permasalahan penegakan hukum di Indonesia saat ini, dan mampu mengangkat kembali derajat hukum di Indonesia sebagai salah satu sarana yang bertujuan utama untuk perlindungan masyarakat dan kesejahteraan masyarakat.

Dari uraian diatas, maka dalam penulisan ini permasalahan yang akan dibahas yaitu: 1) Bagaimanakah metode penemuan hukum dalam putusan hakim pidana yang sesuai dengan karakteristik penemuan hukum yang progresif? 2) Bagaimanakah putusan hakim pidana yang sesuai dengan metode penemuan hukum yang progresif perspektif penologi?

\section{B. HASIL DAN PEMBAHASAN}

Apabila berpijak pada paradigma hukum yang konservatif, maka dalam penemuan hukum yang dilakukan oleh hakim, terlihat hakim hanya mengkonstatir bahwa undangundang dapat diterapkan pada peristiwanya, kemudian hakim menerapkannya menurut bunyi undang-undang. Dengan demikian, penemuan hukum dalam hal ini, tidak lain merupakan penerapan undang-undang yang terjadi secara terpaksa atau sillogisme (Sudikno Mertokusumo dan A. Pitlo.1993:12). Jadi dalam hal ini hakim tidak menemukan hukum baru, dan hanya sekedar menerapkan undang-undang atau hakim hanya sebagai terompet undang-undang saja.

Dalam paradigma penemuan hukum yang konservatif, hukum dan peradilan hanyalah untuk mencegah kemerosotan moral dan nilai-nilai, sedangkan dalam paradigma penemuan hukum yang progresif, hukum dan peradilan merupakan alat untuk melakukan perubahan-perubahan sosial (Ahmad Rifai, 2011:48).

Penemuan hukum yang progresif, berangkat dari konsep 
Ferdy Rizky Adilya, Putusan Hakim Pidana Yang Berkeadilan Substantif Melalui Pendekatan...

hukum progresif, bahwa hukum itu adalah untuk manusia, yang di dalamnya termasuk nilai-nilai akan kebenaran dan keadilan yang menjadi titik pembahasan hukum, sehingga faktor etika dan moralitas tidak terlepas dari pembahasan tersebut. Jadi, penemuan hukum yang progresif secara tegas mengaitkan faktor hukum, kemanusiaan, dan moralitas sehingga penemuan hukum yang dilakukan hakim dalam kerangka menjalankan tugas judisialnya, yang pada akhirnya akan menjatuhkan putusan.

Dengan demikian menurut Ahmad Rifai, karakteristik penemuan hukum yang progresif adalah:

1. Penemuan hukum yang didasarkan atas apresiasi hakim sendiri dengan dibimbing oleh pandangan atau pemikirannya secara mandiri, dengan berpijak pada pandangan bahwa hukum itu ada untuk mengabdi kepada manusia;

2. Penemuan hukum yang bersandarkan pada nilai-nilai hukum, kebenaran, dan keadilan, serta juga etika dan moralitas;

3. Penemuan hukum yang mampu menciptakan nilai-nilai baru dalam kehidupan masyarakat, atau melakukan rekayasa dalam suatu masyarakat yang sesuai dengan perkembangan zaman dan teknologi serta keadaan masyarakat.

Dalam konteks dengan sistem penemuan hukum di Indonesia, pembentuk undangundang tidak memprioritaskan kepada salah satu metode interpretasi atau konstruksi tertentu, oleh karena itu, para hakim bebas menentukan metode interpretasi atau konstruksi hukum yang bagaimanakah yang dianggap paling tepat, meyakinkan, dan memuaskan. Hakim dalam hal ini bersikap otonom dalam menentukan pilihannya. Bahkan dalam putusan-putusan pengadilan pun, hakim tidak pernah menegaskan argumentasi atau alasan penggunaan metode interpretasi atau konstruksi hukum tertentu, bahkan tidak jarang digunakan metode interpretasi atau 
Ferdy Rizky Adilya, Putusan Hakim Pidana Yang Berkeadilan Substantif Melalui Pendekatan...

konstruksi hukum tersebut secara campur aduk atau lebih dari satu jenis interpretasi atau konstruksi hukum (Ahmad Rifai, 2011:9192).

Hakim

menghubungkan antara teks undang-undang dengan suatu peristiwa konkret yang diadilinya, wajib menggunakan pikiran dan nalarnya untuk memilih metode penemuan hukum apa yang paling relevan untuk diterapkannya dalam suatu perkara. Hakim harus jeli, cerdas, adil, dan memiliki wawasan pengetahuan yang luas dan ke depan dalam menentukan pilihan metode interpretasi atau konstruksi karena ketetapan penggunaan metode interpretasi atau konstruksi tertentu akan sangat mempengaruhi putusannya. Hanya dengan demikian, putusan hakim tersebut dapat dinilai adil dan bermanfaat oleh warga masyarakat. Putusan hakim memang hukum, bukan sekadar sumber hukum (Ahmad Rifai, 2011:91-92).

Sebagaimana telah dikemukakan, konsep hukum yang progresif, berangkat dari konsep bahwa hukum itu adalah untuk manusia, yang di dalamnya termasuk nilai-nilai akan kebenaran dan keadilan yang menjadi titik pembahasan hukum, sehingga faktor etika dan moralitas tidak terlepas dari pembahasan tersebut. Jadi, hukum yang progresif secara tegas mengaitkan faktor hukum, kemanusiaan dengan moralitas. Untuk itu, dalam setiap perkara yang diajukan kepadanya, seorang hakim harus tetap berpedoman pada hukum dan peraturan perundang-undangan yang berlaku, dengan tetap menjungjung tinggi akan nilai-nilai kemanusiaan, kebenaran, dan keadilan (Ahmad Rifai, 2011:93).

Dengan mendasarkan pada karakteristik penemuan hukum yang progresif sebagaimana telah dikemukakan sebelumnya, maka metode penemuan hukum yang sesuai dengan karakteristik penemuan hukum yang progresif adalah sebagai berikut:

1. Metode penemuan hukum yang bersifat visioner dengan melihat permasalahan hukum tersebut 
Ferdy Rizky Adilya, Putusan Hakim Pidana Yang Berkeadilan Substantif Melalui Pendekatan...

untuk kepentingan jangka panjang ke depan dengan melihat case by case.

2. Metode penemuan hukum yang berani dalam melakukan suatu terobosan (rule breaking) dengan melihat dinamika masyarakat, tetapi tetap berpedoman pada hukum, kebenaran, dan keadilan serta memihak dan peka pada nasib dan keadaan bangsa dan negaranya.

3. Metode penemuan hukum yang dapat membawa kesejahteraan dan kemakmuran masyarakat dan juga dapat membawa bangsa dan negara keluar dari keterpurukan dan ketidakstabilan sosial seperti saat ini (Ahmad Rifai, 2011:93).

Secara faktual tidak dapat ditentukan metode penemuan hukum yang bagaimanakah yang dapat digunakan hakim dalam melakukan penemuan hukum yang sesuai dengan karakteristik penemuan hukum yang bersifat progresif, karena dalam setiap perkara atau kasus mempunyai bentuk dan karakteristik yang berlainan atau variatif sifatnya, sehingga hakim akan menggunakan metode penemuan hukum yang sesuai dengan kasus yang dihadapinya (case by case), apakah itu salah satu metode interpretasi hukum ataukah salah satu dari metode konstruksi hukum atau hanya berupa gabungan dari beberapa metode interpretasi hukum atau konstruksi hukum, ataukah gabungan dari metode interpretasi hukum dan konstruksi hukum sekaligus (Ahmad Rifai, 2011:93).

Metode interpretasi hukum dilakukan dalam hal peraturannya sudah ada, tetapi tidak jelas untuk dapat diterapkan pada peristiwa konkret, atau mengandung arti pemecahan atau penguraian akan suatu makna ganda, norma yang kabur (vage normen), konflik antarnorma hukum (antinomy normen) dan ketidakpastian dari suatu peraturan perundangundangan. Interpretasi terhadap teks peraturan perundangundangannya pun masih tetap berpegang pada bunyi teks 
tersebut. Tujuannya tidak lain adalah mencari serta menemukan sesuatu hal yang menjadi maksud para pembuatnya (Ahmad Rifai, 2011:93).

Sedangkan konstruksi
hukum dilakukan apabila tidak
diketemukan ketentuan undang-
undang yang secara langsung dapat
diterapkan pada masalah hukum
yang dihadapi, atau dalam hal
peraturannya memang tidak ada,
jadi terdapat kekosongan hukum
(recht vacuum) atau kekosongan
undang-undang (wet vacuum).
Untuk mengisi kekosongan
hukum/undang-undang inilah,
biasanya hakim menggunakan
penalaran logisnya untuk
mengembangkan lebih lanjut suatu
teks undang-undang, di mana
hakim tidak lagi berpegang pada
bunyi teks tersebut (Soedikno

Mertokusumo, 2007:37).

Menurut Ahmad Rifai, bahwa jika dipadukan dengan metode fiksi hukum, dalam hal hakim dianggap tahu akan hukumnya (ius curla novit), maka putusan hakim akan merupakan suatu putusan yang progresif, apabila hakim dalam putusan yang akan dijatuhkannya, ingin keluar dari tawanan undang-undang atau melakukan tindakan contra legem. Pintu masuk yang dapat digunakan oleh hakim dalam hal ini adalah Pasal 5 ayat (1) Undang-Undang Nomor 48 Tahun 2009, dan juga penjelasan dari pasal tersebut, agar putusan yang dijatuhkannya sesuai dengan nilai-nilai kebenaran dan rasa keadilan masyarakat serta dalam rangka mencapai keadilan substansial (Ahmad Rifai, 2011:136).

Pasal 5 ayat (1) UndangUndang Nomor 48 Tahun 2009 tentang Kekuasaan Kehakiman menyatakan bahwa:

"Hakim dan hakim konstitusi wajib menggali, mengikuti, dan memahami nilai-nilai hukum dan rasa keadilan yang hidup dalam masyarakat".

Adapun penjelasan dari pasal tersebut menyatakan bahwa:

"Ketentuan ini dimaksudkan agar putusan hakim sesuai dengan hukum dan rasa keadilan masyarakat".

Bahwa metode penemuan hukum yang sesuai dengan karakteristik penemuan hukum 
Ferdy Rizky Adilya, Putusan Hakim Pidana Yang Berkeadilan Substantif Melalui Pendekatan...

yang progresif adalah metode penemuan hukum yang bersifat visioner dan berani dalam melakukan suatu terobosan (rule breaking) dengan melihat perkembangan masyarakat ke depan, tetapi tetap berpedoman pada kebenaran dan keadilan serta memihak dan peka pada nasib dan keadaan bangsa dan negaranya, sehingga dapat membawa kesejahteraan dan kemakmuran masyarakat dan juga dapat membawa bangsa dan negara keluar dari keterpurukan dan ketidakstabilan sosial.

Berdasarkan hal tersebut, menurut Ahmad Rifai (2011:137138), putusan hakim yang sesuai dengan metode penemuan hukum yang progresif adalah:

1. Putusan hakim tidak hanya semata-mata bersifat legalistik, yakni hanya sekadar menjadi corong undang-undang (la bouche de la loi) meskipun memang seharusnya hakim selalu harus legalistik karena putusannya tetap berpedoman pada peraturan perundangundangan yang berlaku;
2. Putusan hakim tidak hanya sekadar memenuhi formalitas hukum atau sekadar memelihara ketertiban saja, tetapi putusan hakim harus berfungsi mendorong perbaikan dalam masyarakat dan membangun harmonisasi sosial dalam pergaulan;

3. Putusan hakim yang mempunyai visi pemikiran ke depan (visioner), yang mempunyai keberanian moral untuk melakukan terobosan hukum (rule breaking), di mana dalam hal suatu ketentuan undang-undang yang ada bertentangan dengan kepentingan umum, kepatutan, peradaban, dan kemanusiaan, yakni nilai-nilai yang hidup dalam masyarakat, maka hakim bebas dan berwenang melakukan tindakan contra legem, yaitu mengambil putusan yang bertentangan dengan pasal undang-undang yang bersangkutan, dengan tujuan untuk mencapai kebenaran dan keadilan; 
4. Putusan hakim yang memihak dan peka pada nasib dan keadaan bangsa dan megaranya, yang bertujuan pada peningkatan kesejahteraan untuk kemakmuran masyarakat serta membawa bangsa dan negara keluar dari keterpurukan dalam segala bidang kehidupan.

Metode penemuan hukum perspektif penologi diperoleh berdasarkan pendekatan atau gagasan dari hukum progresif yang merupakan suatu bagian dari proses pencari kebenaran yang tidak pernah berhenti dan menciptakan keadilan substantif. Hukum progresif yang dapat dipandang sebagai konsep yang sedang mencari jati diri bertolak dari realitas empiris tentang bekerjanya hukum di masyarakat, berupa ketidakpuasan dan keprihatinan terhadap kinerja dan kualitas penegak hukum di Indonesia. (Satjipto Rahardjo, 2005). Kehadiran hukum progresif yang berangkat dari asumsi dasar bahwa hukum adalah untuk manusia dan selalu dalam proses untuk menjadi, maka dalam memberikan penjelasan terhadap fenomena hukum, akan melibatkan teori hukum lain (Yudi Kristiana, 2009:21).

Karena hukum itu untuk manusia, maka penegak hukum seharusnya bukan hanya sekedar memahami hukum positif yang selama ini berlaku saja, tetapi bagaimana seorang penegak hukum itu mampu mengangkat nilai-nilai hukum yang bermuara kepada sebuah keadilan yang sesungguhnya, bukan hanya keadilan yang berdasarkan rentetan kata-kata atau kalimat peraturan perundang-undangan saja, tetapi lebih kepada keadilan yang nyata. (Hartono, 2010:17).

Dalam hukum progresif, proses perubahan tidak lagi berpusat pada peraturan, akan tetapi pada kreatifitas pelaku hukum mengaktualisasikan hukum dalam ruang dan waktu yang tepat. Para pelaku hukum progresif dapat melakukan perubahan dengan melakukan pemaknaan yang kreatif terhadap peraturan yang ada, tanpa harus menunggu perubahan peraturan. Peraturan 
Ferdy Rizky Adilya, Putusan Hakim Pidana Yang Berkeadilan Substantif Melalui Pendekatan...

yang buruk tidak harus menjadi penghalang bagi para pelaku hukum progresif untuk menghadirkan keadilan bagi rakyat dan pencari keadilan, karena mereka dapat melakukan interpretasi secara baru setiap kali terhadap suatu peraturan (M. Syamsudin, 2011:26).

Bahwa karena hukum progresif yang menjadi pusat perhatian adalah manusia, maka eksistensi manusia yang kreatif dalam konteks penegakan hukum ditempatkan oleh hukum progresif untuk mengatasi ketertinggalan hukum, ketimpangan hukum, juga untuk membuat terobosanterobosan hukum. Terobosan hukum inilah yang diharapkan dapat mewujudkan kebahagiaan bagi manusia dan keadilan substantif bukan prosedural saja melalui bekerjanya hukum.

Putusan hakim perspektif penologi tidak lepas dari ruang lingkup penologi yaitu jenis pidana, tujuan pemidanaan, efektivitas pemidanaan dan dampak pemidanaan. Putusan hakim pidana dalam penentuan jenis pidana dan tujuan pemidanaan yang berkeadilan substantif melalui pendekatan hukum progresif, penegak hukum baik penyidik, penuntut umum, maupun pengadilan sebenarnya dapat menerapkan sifat melawan hukum materil dalam penegakan hukum. Penegak hukum khususnya hakim dituntut untuk berpikir kreatif dalam melakukan penemuan hukum. Disamping aturan-aturan yang diundangkan, saat ini juga tetap berkembang aturan-aturan yang tidak diundangkan yang terus hidup dalam masyarakat, yang bahkan justru aturan-aturan yang tidak diundangkan itu dirasakan lebih adil. Banyak aturan yang diundangkan kurang berhasil. Aturan aturan itu tidak akan didukung apabila bertentangan dengan aturan-aturan yang masih dianut dalam masyarakat sekalipun tidak diundangkan.

Hukum pidana adalah suatu codex, dan karena sifatnya sebagai codex, jauh dari sempurna, karena itu, hakim sering mencari keadilan dalam nilai-nilai masyarakat (M. 
Ferdy Rizky Adilya, Putusan Hakim Pidana Yang Berkeadilan Substantif Melalui Pendekatan...

Syamsudin, 2011:5). Keadilan dalam nilai-nilai masyarakat tersebut dimaksud adalah norma hukum materil. Dengan demikian secara progresif, dalam pengambilan putusan dan penentuan jenis pidana atau lama pidananya, hakim dapat juga berdasar pada norma hukum materil yang tumbuh dan berkembang di dalam masyarakat. Baik dalam putusan pidana pada akhirnya, maupun dalam putusan lepas dari segala tuntutan hukum.

Bahwa hal tersebut juga bukan merupakan hal baru dalam penegak hukum dan tidak bertentangan dengan perundangundangan yang berlaku. Terbukti dengan adanya yurisprudensiyurisprudensi sebelumnya. Sebagaimana diketahui yurisprudensi di Indonesia merupakan juga salah satu sumber hukum formil selain undangundang, kebiasaan, traktat dan doktrin. Dengan demikian demi mendapatkan suatu keadilan yang nyata atau secara substantif benarbenar dirasakan adanya, dengan berpikir kreatif secara progresif hakim pidana dalam penjatuhan putusan dapat menggunakan norma hukum materil sebagai penentu perbuatan pidana atau bukan perbuatan pidana atau dalam penentuan unsur objektif dari tindak pidana.

Sedangkan dalam penentuan pertanggungjawaban pidananya atau unsur subjektif, hakim harus menganalisis apakah terdakwa dapat dinyatakan bertanggung jawab atas perbuatan pidana yang dilakukannya. Pada saat menyelidiki apakah terdakwa yang melakukan perbuatan pidana dapat mempertanggungjawabkan perbuatannya, yang dipandang primer adalah orang itu sendiri. Sebagaimana diketahui dapat dipidananya seorang harus memenuhi dua syarat, yaitu pertama, perbuatan yang bersifat melawan hukum formil ataun materil sebagai sendi perbuatan pidana, dan yang kedua, perbuatan yang dilakukan itu dapat dipertanggungjawabkan sebagai suatu kesalahan (asas geen straf zonder schuld). 
Ferdy Rizky Adilya, Putusan Hakim Pidana Yang Berkeadilan Substantif Melalui Pendekatan...

Namun demikian, dalam hal analisis hakim terhadap pelaku tindak pidana ternyata sehat lahir dan batinnya serta tidak adanya alasan pemaaf maupun alasan pembenar yang dapat menghapuskan sifat melawan hukum dari perbuatan pidana yang dilakukan oleh pelaku, maka hakim menyatakan pelaku sebagai orang yang dapat mempertanggungjawabkan

perbuatannya di hadapan hukum.

Bahwa demikian, dalam penentuan jenis pidana oleh hakim setelah penentuan unsur objektif dan subjektif dilakukan dan berdasarkan fakta di persidangan terdakwa terbukti secara sah dan meyakinkan bersalah melakukan tindak pidana, hakim dapat memberikan jenis pidana yang pantas dan "setimpal" dengan tindak pidana yang dilakukannya, apakah hanya berupa pidana pokok saja ataupun dengan pidana tambahan. Tentunya hal tersebut juga berdasar dengan delik tindak pidana yang telah dirumuskan didalam undang-undang sebelumnya, terkecuali jika hakim memandang perbutan tersebut sangat dirasakan tercela oleh negara dan atau masyarakat, hakim dapat melakukan terobosan hukum berupa penjatuhan jenis pidana pokok dan pidana tambahan sekaligus selain juga yang telah ditentukan didalam undang-undang khusus sebelumnya. Hal tersebut dirasa perlu jika dalam suatu kondisi yang sudah seharusnya hakim mengambil keputusan yang progresif dan berpihak kepada nilai-nilai yang hidup didalam masyarakat sehingga mencerminkan keadilan substantif selain juga keadilan formil.

Bahwa tentang penentuan tujuan pemidanaan dalam putusan hakim, pada hakikatnya dapat menjadi dasar pemikiran dari penjatuhan sanksi pidana, mengapa seseorang dijatuhi pidana bagi orang yang melanggar dan apa yang diharapkan dengan memidana seseorang. Besar harapan agar tujuan pemidanaan, dapat dikaitkan pula dengan nilainilai sosial, budaya dan struktural yang hidup dan berkembang di masyarakat Indonesia, sesuai 
Ferdy Rizky Adilya, Putusan Hakim Pidana Yang Berkeadilan Substantif Melalui Pendekatan...

dengan nilai-nilai yang terkandung dalam Pancasila. Karena salah satu alat atau cara untuk mencapai tujuan hukum pidana adalah memidana seseorang yang telah melakukan suatu tindak pidana.

Dalam praktiknya tujuan pemidanaan dapat dikumulasikan perpaduan teori pembalasan dengan teori tujuan, yang disebut sebagai teori gabungan. Teori tersebut tetap dipertahankan sebagai pondasi awal untuk mempertimbangkan masa lalu (seperti yang terdapat dalam teori pembalasan), tetapi juga harus bersamaan mempertimbangkan masa datang (seperti yang dimaksudkan pada teori tujuan). Dengan demikian penjatuhan suatu pidana akan memberikan rasa kepuasan, baik bagi hakim maupun kepada penjahat itu sendiri di samping kepada masyarakat (S.R.

\section{Sianturi, 1996:62).}

Putusan hakim pidana dalam penentuan Efektivitas Pemidanaan dan Dampak pemidanaan yang berkeadilan substantif melalui pendekatan hukum progresif, hakim dapat menggunakan beberapa teori atau pendekatan dalam mempertimbangkan penjatuhan putusan dalam suatu perkara, yaitu teori keseimbangan sebagai Efektifitas Pemidanaan, yaitu keseimbangan antara syaratsyarat yang ditentukan oleh undang-undang dan kepentingan pihak-pihak yang tersangkut atau berkaitan dengan perkara, yaitu antara lain seperti adanya keseimbangan yang berkaitan dengan kepentingan masyarakat, kepentingan terdakwa dan kepentingan korban, atau kepentingan pihak penggugat dan pihak tergugat.

Teori Pendekatan Seni dan Intuisi sebagai Efektifitas Pemidanaan. Penjatuhan putusan oleh hakim merupakan diskresi atau kewenangan dari hakim. Sebagai diskresi, dalam penjatuhan putusan, hakim akan menyesuaikan dengan keadaan dan hukum yang wajar bagi setiap pelaku tindak pidana atau dalam perkara perdata, hakim akan melihat keadaan pihak yang berperkara, yaitu penggugat dan tergugat, dalam perkara perdata, 
Ferdy Rizky Adilya, Putusan Hakim Pidana Yang Berkeadilan Substantif Melalui Pendekatan...

dan pihak terdakwa atau Penuntut Umum dalam perkara pidana. Pendekatan seni dipergunakan oleh hakim dalam penjatuhan suatu putusan, lebih ditentukan oleh instink atau intuisi daripada pengetahuan dari hakim.

Teori Pendekatan Keilmuan sebagai Efektifitas Pemidanaan. Titik tolak dari teori ini adalah pemikiran bahwa proses penjatuhan pidana harus dilakukan secara sistematik dan penuh kehati-hatian, khususnya dalam kaitannya dengan putusan-putusan terdahulu dalam rangka menjamin konsistensi dari putusan hakim. Pendekatan keilmuan ini merupakan semacam peringatan bahwa dalam memutus suatu perkara, hakim tidak noleh sematamata atas dasar intuisi atau instink semata, tetapi harus dilengkapi dengan ilmu pengetahuan hukum dan juga wawasan keilmuan hakim dalam menghadapi suatu perkara yang harus diputuskannya.

Teori

Pendekatan

Pengalaman sebagai Dampak

Pemidanaan. Pengalaman dari seorang hakim merupakan hal yang dapat membantunya dalam menghadapi perkara-perkara yang dihadapinya sehari-hari, karena dengan pengalaman yang dimiliknya, seorang hakim dapat mengetahui bagaimana dampak dari putusan yang dijatuhkan dalam suatu perkara pidana, yang berkaitan dengan pelaku, korban maupun masyarakat, ataupun dampak yang ditimbulkan dalam putusan perkara perdata yang berkaitan pula dengan pihak-pihak yang berperkara dan juga masyarakat.

Teori Ratio Decidendi sebagai Dampak Pemidanaan. Teori ini didasarkan pada landasan filsafat yang mendasar, yang mempertimbangkan segala aspek yang berkaitan dengan pokok perkara yang disengketakan, kemudian mencari peraturan perundang-undangan yang relevan dengan pokok perkara yang disengketakan sebagai dasar hukum dalam penjatuhan putusan, serta pertimbangan hakim harus didasarkan pada motivasi yang jelas untuk menegakkan hukum 
Ferdy Rizky Adilya, Putusan Hakim Pidana Yang Berkeadilan Substantif Melalui Pendekatan...

dan memberikan keadilan bagi para pihak yang berperkara.

Teori Kebijaksanaan sebagai Dampak Pemidanaan. Teori kebijaksanaan ini diperkenalkan oleh Made Sadhi Astuti, di mana sebenarnya teori ini berkenaan dengan putusan hakim dalam perkara di pengadilan anak. Landasan dari teori kebijaksanaan ini menekankan rasa cinta terhadap tanah air, nusa, dan bangsa Indonesia serta kekeluargaan harus ditanam, dipupuk, dan dibina. Selanjutnya, aspek teori ini menekankan bahwa pemerintah, masyarakat, keluarga, dan orang tua, ikut bertanggung jawab untuk membimbing, membina, mendidik, dan melindungi anak, agar kelak dapat menjadi manusia yang berguna bagi keluarga, masyarakat, dan bagi bangsanya.

\section{PENUTUP}

\section{Simpulan}

a. Penemuan hukum dengan metode interpretasi atau konstruksi hukum dan atau gabungan keduanya dengan konsep hukum progresif. b. Putusan hakim pidana dalam penentuan jenis pidana menerapkan sifat melawan hukum materil dan penjatuhan jenis pidana pokok dan pidana tambahan sekaligus, dalam penentuan tujuan pemidanaan dikaitkan dengan Pancasila dan menggunakan teori gabungan, dalam efektifitas pemidanaan melalui teori keseimbangan, teori pendekatan seni dan intuisi juga melalui teori pendekatan keilmuan, dan dampak pemidanaan melalui teori pendekatan pengalaman, teori ratio decidendi, dan teori kebijaksanaan.

\section{Saran}

a. Penerapannya agar hati-hati dan tidak berlebihan diluar dari konsep hukum progresif, karena menggunakan sarana hukum pidana yang dikenal dengan "pedang bermata dua" dan dapat dijadikan konsep dasar pembaharuan hukum di Indonesia, baik 
secara formil maupun materiil.

b. Dapat diterapkan oleh hakim tanpa harus menunggu adanya aturan yang mengaturnya dan dalam rangka penanggulangan kejahatan dan meninjau kembali pemidanaan, perspektif penologi dapat digunakan tentunya melalui pendekatan hukum progresif.

\section{DAFTAR PUSTAKA}

\section{Al-Qur'an Al Karim dan Terjemahnya, PT. Karya Toha Putra Semarang, Semarang, Edisi 2002.}

\section{Ahmad Rifai, Penemuan Hukum oleh Hakim dalam Perspektif Hukum Progresif, Sinar Grafika, Jakarta, 2011.}

Bagir Manan, Wajah Hukum di Era Reformasi, Citra Aditya Bakti, Bandung, 2000.

$$
\begin{gathered}
\text { Hartono, Penyidikan } \& \\
\text { Penegakan } r \text { Hukum } \\
\text { Pidana } r \text { Melalui } \\
\text { Pendekatan Hukum } \\
\text { Progresif, Sinar Grafika, } \\
\text { Jakarta, 2010. } \\
\text { Mochtar Kusumaatmaja, Konsep- } \\
\text { Konsep Hukum dalam }
\end{gathered}
$$

Pembangunan, Alumni, Bandung, 2002.

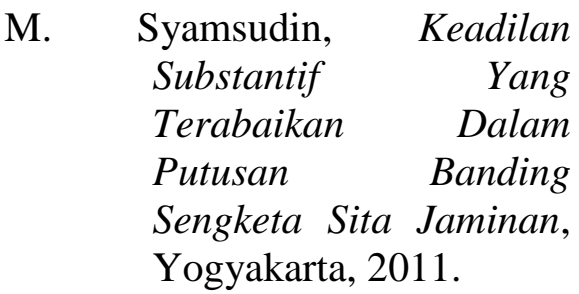

S. R Sianturi, Asas-Asas Hukum Pidana di Indonesia dan Penerapannya, Alumni Ahaem-Petehaem, Jakarta, 1996.

Satjipto Rahardjo, Hukum Progresif: Hukum yang Membebaskan, Jurnal Hukum Progresif, Vol. 1/No. 1/ April 2005, PDIH Ilmu Hukum UNDIP. , Hukum Progresif (Penjelajahan Suatu Gagasan), Newsletter No. 59 Bulan Desember 2004, Yayasan Pusat Pengkajian Hukum, Jakarta, 2004.

Sudikno Mertokusumo dan A. Pitlo, Bab-Bab tentang Penemuan Hukum, Citra Aditya Bakti, Bandung, 1993.

Yudi Kristiana, Menuju Kejaksaan Progresif, menuju Kejaksaan Progresif: Studi Tentang Penyelidikan, penyidikan dan Penuntutan Tindak Pidana, ctk. Pertama, 
Ferdy Rizky Adilya, Putusan Hakim Pidana Yang Berkeadilan Substantif Melalui Pendekatan...

LSHP, Yogyakarta, 2009.

Undang-Undang Nomor 48 Tahun 2009 Tentang Kekuasaan Kehakiman. 